ARTIKEL PENELITIAN

\title{
Scoping Review: Pengaruh Terapi TURP terhadap Benign Prostatic Hyperplasia pada Lansia
}

\author{
Dito Dewantoro Satriawan, ${ }^{1}$ Meta Maulida Damayanti, ${ }^{2}$ Diana Wijayanti ${ }^{3}$ \\ ${ }^{1}$ Faculty of Medicine, Universitas Islam, Bandung, Indonesia \\ ${ }^{2}$ Faculty of Medicine, Universitas Islam, Bandung, Indonesia \\ ${ }^{3}$ Department of Dermatology and Venerelogy, Muhammadiyah Hospital Bandung, Indonesia
}

\begin{abstract}
Abstrak
Benign prostatic hyperplasia $(\mathrm{BPH})$ merupakan istilah histopatologis, yaitu hiperplasia sel stroma dan sel epitel kelenjar prostat, dan bersifat jinak. Prevalensi BPH terjadi sekitar $70 \%$ pada pria di atas usia 60 tahun. Tujuan terapi pada pasien BPH adalah memperbaiki kualitas hidup pasien. Salah satu pilihan terapi untuk BPH yaitu transurethral resection of prostate (TURP) yang merupakan metode paling banyak digunakan untuk mengatasi pembesaran prostat. Tujuan penelitian ini adalah melihat gambaran pengaruh terapi TURP terhadap BPH pada lansia. Penelitian ini merupakan Scoping Review, yang diambil dari database PubMed, Springer Link, dan Science Direct dengan metode original research articles (observasional). Penelitian ini dinilai secara PICOS untuk ditentukan sebagai kriteria eligible pada prisma flow chart yang sesuai yaitu population (pasien BPH, lansia), intervention (terapi TURP), comparison (terapi lain), outcome (kesembuhan pasien BPH) terdapat 10.025 artikel, dan hasil uji berdasar atas PICOS sebanyak 10 artikel. Hasil analisis dan review dari 10 artikel ini, yaitu terapi TURP memiliki banyak fungsi serta manfaat untuk perbaikan kondisi pasien. Indikator tersebut dapat dinilai dari penurunan risiko perdarahan, waktu operasi, waktu irigasi kandung kemih, durasi kateterisasi, durasi rawat inap, perbaikan pada IPSS, QoL, Qmax, PVR, Na+ serum, K+ serum, kadar hematokrit, volume cairan irigasi, kadar hemoglobin, kreatinin serum, volume prostat dasar, IIEF-5, CTCAE, SHIM, MSHQ-EjD, dan ISI. Pasien BPH juga dapat mengalami risiko komplikasi intraoperatif ataupun pascaoperatif. Kesimpulan penelitian ini menunjukkan bahwa pengaruh terapi TURP terhadap BPH pada lansia mempunyai hasil yang cukup baik, efisien, dan efektif.
\end{abstract}

Kata kunci: Benign prostatic hyperplasia, lansia, terapi TURP

\section{Scoping Review: the Effect of TURP Therapy on Benign Prostatic Hyperplasia in the Elderly}

\begin{abstract}
Benign prostatic hyperplasia (BPH) is a histopathological term, which is hyperplasia of stromal cells and epithelial cells of the prostate gland, and is benign. The prevalence of BPH occurs in about 70\% in men over the age of 60 . The goal of therapy in BPH patients is to improve the patient's quality of life. One of the treatment options for $\mathrm{BPH}$ is the transurethral resection of prostate (TURP) which is the most widely used method to treat an enlarged prostate. The purpose of this study was to describe the effect of TURP therapy on BPH in the elderly. This research is a Scoping Review, which is taken from the PubMed, Springer Link, and Science Direct databases using the original research articles (observational) method. This study was assessed by PICOS to be determined as eligible criteria on the appropriate prism flow chart, namely population (BPH patients, the elderly), intervention (TURP therapy), comparison (other therapies), 10,025 articles of outcome (recovery of BPH patients), and test results. based on PICOS as many as 10 articles. The results of the analysis and review of these 10 articles are: TURP therapy has many functions and benefits for improving the patient's condition. These indicators can be assessed from the decreased risk of bleeding, time of operation, time of bladder irrigation, duration of catheterization, duration of hospitalization, improvement in IPSS, QoL, Qmax, PVR, serum Na +, serum $\mathrm{K}+$, levels of hematocrit, volume of irrigation fluid, hemoglobin levels, serum creatinine, baseline prostate volume, IIEF-5, CTCAE, SHIM, MSHQ-EjD, and ISI. Patients with BPH may also be at risk of intraoperative or postoperative complications. The conclusion of this study shows that the effect of TURP therapy on BPH in the elderly has good, efficient and effective results.
\end{abstract}

Keywords: Benign prostatic hyperplasia, the elderly, TURP therapy

Received: 8 ...; Revised: ...; Accepted: ...; Published: ...

Koresponden: Dito Dewantoro Satriawan. Program Pendidikan Sarjana Kedokteran Fakultas Kedokteran Universitas Islam Bandung. Jl. Taman Sari No.22, Kota Bandung, Provinsi Jawa Barat. Telepon : 082115356777. Email: ditotiga51@yahoo.co.id 


\section{Pendahuluan}

Benign Prostatic Hyperplasia (BPH) merupakan istilah histopatologis, yaitu adanya hiperplasia sel stroma dan sel epitel kelenjar prostat, ${ }^{1}$ dan bersifat jinak. ${ }^{2}$ Prevalensi BPH meningkat seiring dengan bertambahnya usia ( $>40$ tahun), dimana terjadi sekitar $70 \%$ pada pria di atas usia 60 tahun dan akan meningkat hingga $90 \%$ pada pria berusia di atas 80 tahun. Penelitian mengenai angka kejadian $\mathrm{BPH}$ di Indonesia masih terbatas, prevalensi BPH di Rumah Sakit Cipto Mangunkusumo dari tahun 19942013 ditemukan 3.804 kasus dengan rata-rata umur penderita berusia 66,61 tahun. Sedangkan data yang didapatkan dari Rumah Sakit Hasan Sadikin dari tahun 2012-2016 ditemukan 718 kasus dengan ratarata umur penderita berusia 67,9 tahun. ${ }^{3}$

Tujuan terapi pada pasien $\mathrm{BPH}$ adalah untuk memperbaiki kualitas hidup pasien. Pilihan terapinya adalah: 1. Konservatif (watchful waiting), 2. Medikamentosa, 3. Pembedahan, dan 4. Lain-lain (kondisi khusus). Pelaksanaan terapi didiskusikan terlebih dahulu dengan pasien dan tergantung pada derajat keluhan, keadaan pasien, serta ketersediaan fasilitas setempat. ${ }^{4}$

Transurethral Resection of Prostate (TURP) merupakan salah satu terapi dengan metode minimum intervention operative yang banyak digunakan (gold standard) untuk mengatasi pembesaran prostat dan sebagian besar rumah sakit melakukan TURP pada pasien yang dicurigai $\mathrm{BPH}^{5}$, sehingga peneliti tertarik melakukan scoping review: pengaruh terapi TURP terhadap BPH pada lansia.

\section{Metode}

Jenis penelitian yang digunakan adalah Scoping Review. Fokus penelitian ini adalah pengaruh terapi TURP terhadap BPH pada lansia. Sampel dalam penelitian ini berjumlah 10 artikel penelitian dari jurnal nasional dan internasional yang berkaitan dengan judul penelitian yang sesuai dengan kriteria inklusi dan ekslusi.

Pencarian data melalui sumber database PubMed, Springer Link, dan Science Direct, sedangkan kata kunci yang digunakan adalah ("Prostatic Hyperplasia"[Mesh]) AND "Transurethral Resection of Prostate"[Mesh]; Benign Prostatic Hyperplasia AND Transurethral Resection of Prostate; Benign Prostatic Hyperplasia AND Transurethral Resection of Prostate.

Literatur yang diakses dalam proses penelitian ini diskrining berdasar atas kriteria berikut: artikel penelitian diterbitkan dalam rentang waktu 10 tahun (2010-2020); tipe artikel penelitian original research article (observasional); artikel penelitian yang dapat diakses secara penuh (full text); dan artikel berbahasa Inggris dan berbahasa Indonesia. Artikel yang didapat dipilih berdasar atas kesesuaian dengan kriteria PICOS: Population (pasien BPH, lansia), Intervention (terapi TURP), Comparison (terapi lain), Outcome (kesembuhan BPH), Study (observasional).

Penilaian kualitas atau kelayakan pada penelitian ini didasarkan pada kriteriia inklusi dan eksklusi penelitian. Semua data berupa artikel penelitian yang sesuai dengan kriteria kelayakan di-review dan dianalisis secara kualitatif. Hasil keseluruhan artikel yang memenuhi syarat untuk di-review sebanyak 10 artikel yang disajikan.

\section{Hasil}

Pencarian literatur menghasilkan 11.025 artikel dan diskrining berdasar atas tahun, bahasa, duplikasi, dan tipe artikel sehingga tersisa 361 artikel. Dari jumlah tersebut, 351 artikel di eksklusi karena ketidaksesuaian antara judul artikel dan abstrak (kesesuaian abstrak berdasar atas PICOS). Sehingga tersisa 10 artikel dengan teks lengkap dinilai kelayakannya, dan dimasukkan dalam review ini disajikan dalam diagram PRISMA pada Gambar 1.

\section{Gambar 1 Prisma Flow Diagram}

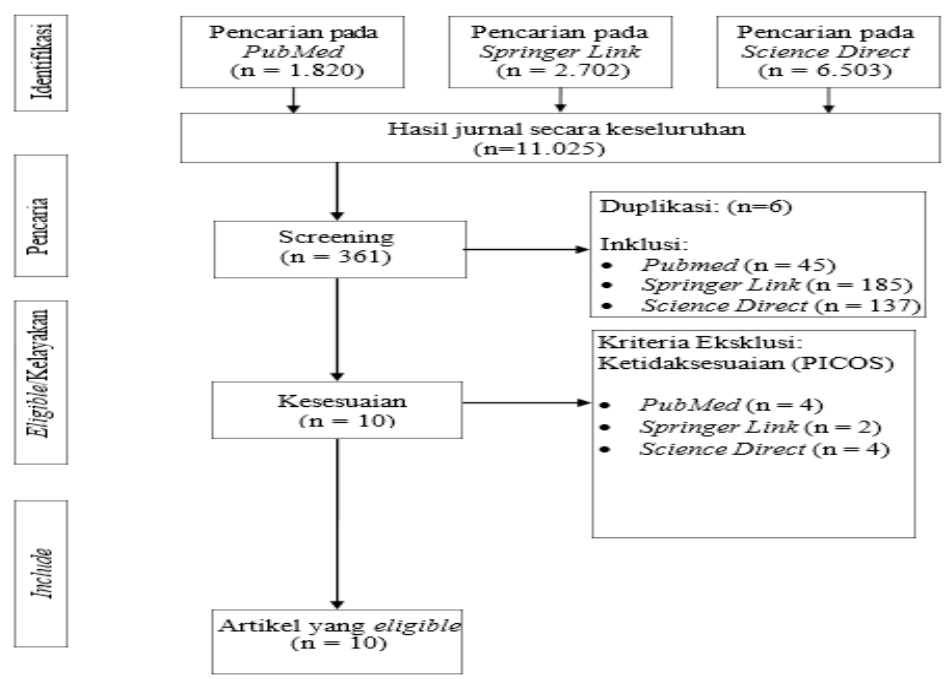


Jumlah artikel yang layak di-review sebanyak 10 artikel. Hasil scoping review pengaruh terapi TURP terhadap BPH pada lansia dapat dilihat pada Tabel berikut.

\begin{tabular}{lll}
\hline Reference & Study Design & Methods \\
\hline \multirow{2}{*}{ Jun Zhang dkk $^{6} \quad$ Single-blinded $R C T^{6}$} & Evaluasi sebelum operasi dan 3, 6, \\
& & \\
& & dari risiko perdarahan, waktu operasi, \\
& waktu irigasi kandung kemih, durasi \\
& kateterisasi, durasi rawat inap, \\
& International Prostate Symptom Score \\
& (IPSS), quality of life (QoL), maximum \\
& urinary flow rate (Qmax), dan postvoid \\
& residual urine (PVR).
\end{tabular}

Elsakka dkk ${ }^{7}$

Prospective

randomised controlled study

Kasivisvanathan Cohort study ${ }^{8}$ $\mathrm{dkk}^{8}$

Falahatkar dkk

Single-center prospective randomized trial $^{9}$

Yang $\mathrm{dkk}^{10}$
Retrospective study ${ }^{10}$
Kedua teknik dievaluasi berdasarkan laporan perioperatif dari perubahan serum $\mathrm{Na}+$, serum $\mathrm{K}+$, hematokrit, dan komplikasi perioperatif. Dan untuk kemanjurannya, pasien dievaluasi dengan membandingkan peningkatan pada International Prostate Symptom Score (IPSS), mengukur maximum urinary flow rate (Qmax), dan postvoid residual urine (PVR) baik sebelum dan sesudah prosedur. ${ }^{7}$

Untuk kemanjuran bisa dilihat dari perubahan IPSS hingga 1 tahun dari baseline. Untuk keamanan dapat dilihat dari proporsi subjek dengan adanya efek samping hingga 1 tahun yang dinilai melalui kejadian klinis sebagai mungkin atau pasti terkait dengan prosedur penelitian yang diklasifikasikan dengan klasifikasi clavien-dindo grade 2 atau lebih tinggi atau kejadian grade 1 yang mengakibatkan kecacatan persisten (disfungsi ejakulasi atau ereksi atau inkontinensia). ${ }^{8}$

Parameternya termasuk waktu operasi, volume cairan irigasi, periode kateterisasi, tinggal di rumah sakit pasca operasi, komplikasi dan perubahan kadar hemoglobin, kreatinin serum, natrium dan kalium pasca operasi dinilai

pada semua pasien. Juga tiga bulan setelah prosedur, IPSS dan Qmax diukur untuk evaluasi kemanjuran dalam semua kasus. ${ }^{9}$

Kadar natrium dan hemoglobin serum dikumpulkan dalam waktu 4 jam pasca operasi. Empat hasil fungsional termasuk perbaikan IPSS, QoL, Qmax dan PVR dievaluasi 4 minggu kemudian di klinik urologi. Dan juga menggunakan beberapa pembaur potensial seperti usia, BMI, volume prostat dasar, tingkat pendidikan dan pendapatan tahunan sebagai kovariat untuk penyesuaian IPSS dan kualitas hidup dalam analisis subkelompok. ${ }^{10}$

\section{Result}

DiLEP dan PKRP memiliki kemanjuran dan keamanan yang serupa untuk meredakan obstruksi dan gejala saluran kemih bawah. DiLEP menurunkan risiko perdarahan, waktu operasi, waktu irigasi kandung kemih, durasi kateterisasi, dan rawat inap. Namun, IPSS, QoL, Qmax, dan PVR serupa untuk kedua prosedur dalam 12 bulan pasca operasi.

Secara sekilas B-TUPV terlihat lebih aman dibandingkan dengan M-TURP, akan tetapi terdapat kekurangan yang signifikan pada B-TUPV yaitu kurangnya spesimen jaringan dan relatif tinggi rate retreatment pada B-TUPV. Dan juga M-TURP lebih efektif daripada B-TUPV dimana keamanannya bisa ditingkatkan dengan pemilihan kasus yang tepat/hati-hati dan menjaga hemostasis agar tetap adekuat.?

Aquablation menunjukkan perbaikan LUTS pada 1 tahun sebanding dengan TURP, akan tetapi lebih memiliki sedikit risiko efek samping dan disfungsi ejakulasi. Dimana aquablation, dengan waktu operasi dan reseksi rata-rata yang lebih pendek, kemanjuran yang sebanding TURP dan lebih sedikit potensi efek sampingnya, adalah alternatif yang tepat untuk hasil 1 tahun yang lebih baik untuk pria dengan prostat antara 30 cc-8o cc. Selain itu, in adalah pilihan yang sangat baik untuk pria yang ingin mempertahankan fungsi ejakulasi mereka. ${ }^{8}$

B-TUVP adalah prosedur yang aman, efektif dengan biaya yang cukup terjangkau diantara operasi invasif minimal BPH. Dibandingkan dengan B-TURP, B-TUVP memiliki komplikasi yang sama, hasil perioperatif dan pasca operasi yang lebih baik, hemostasis yang lebih baik dan kemanjuran yang lebih tinggi. ${ }^{9}$

Dibandingkan dengan TURP, HPS menghasilkan peningkatan IPSS, QoL, Qmax dan PVR yang sebanding dengannya, tetapi memiliki durasi rawat inap yang lebih pendek, kehilangan hemoglobin serum yang lebih sedikit dan laju transfusi darah yang lebih rendah. Pria pada kelompok HPS lebih muda (usia <76 tahun), memiliki BMI yang lebih tinggi $(\geq 24 \mathrm{~kg} / \mathrm{m} 2)$ dan perbaikan yang lebih baik pada IPSS dan kualitas hidup. ${ }^{10}$ 


\begin{tabular}{|c|c|c|}
\hline Sinanoglu dkk ${ }^{11}$ & Retrospective study ${ }^{11}$ & $\begin{array}{l}\text { Mengevaluasi secara preoperatif } \\
\text { dan postoperatif selama } 12 \text { bulan } \\
\text { yang dinilai dari International } \\
\text { Prostate Symptom Score (IPSS), } \\
\text { maximal urinary flow rate (Qmax), } \\
\text { postoperative International Index of } \\
\text { Erectile Function scores (IIEF), dan } \\
\text { urethral stricture rates. }{ }^{11}\end{array}$ \\
\hline Sood dkk ${ }^{12}$ & $\begin{array}{l}\text { Prospective } \\
\text { randomised study }{ }^{12}\end{array}$ & $\begin{array}{l}\text { Faktor intraoperatif yang dinilai } \\
\text { adalah waktu operasi; skor nyeri/ } \\
\text { ketidaknyamanan; jumlah irigasi dan } \\
\text { iv cairan yang digunakan; persyaratan } \\
\text { transfusi darah; dan komplikasi } \\
\text { intraoperatif, seperti perdarahan } \\
\text { dan perforasi sinus kapsular / vena; } \\
\text { dan sindrom TUR. Nyeri dinilai } \\
\text { menggunakan skala analog visual (VAS; } \\
\text { kisaran o-10) Pasca operasi dibuat } \\
\text { catatan tentang jumlah dan durasi } \\
\text { irigasi; waktu traksi; retensi bekuan; } \\
\text { Skor nyeri VAS pada 1, } 3 \text { dan 6 jam; } \\
\text { persyaratan analgesik; penurunan } \\
\text { hemoglobin; dan ketidakseimbangan } \\
\text { elektrolit. Pasien dipulangkan setelah } \\
\text { urin bersih setelah irigasi dihentikan } \\
\text { selama } 2 \text { jam. Disuria dinilai pada skala } \\
\text { 1-10. Setiap komplikasi dalam periode } \\
\text { pasca operasi dicatat dan ditangani } \\
\text { dengan tepat. }{ }^{2}\end{array}$ \\
\hline
\end{tabular}

\section{Müllhaupt dkk $\mathrm{d}^{13} \quad$ Randomized} controlled trial ${ }^{13}$

Enikeev dkk ${ }^{14}$
Retrospective study ${ }^{14}$
Penilaian fungsi ejakulasi menggunakan klasifikasi Common Terminology Criteria for Adverse Events (CTCAE), yaitu grade 1: diminished, dan grade 2: anejaculation/retrograde ejaculation. ${ }^{13}$$$
3
$$

Untuk keamanan dan kemanjuran prosedur lebih baik pada PAE dibandingkan dengan TURP. Dimana gangguan ejakulasi lebih sering terjadi pada TURP yaitu $84 \%$, dibandingkan dengan PAE yaitu 56\%. Meskipun anejakulasi terjadi lebih jarang terjadi setelah PAE (16\%) dibandingkan dengan TURP (52\%), pasien harus diberitahu tentang risiko gangguan ejakulasi untuk kedepannya. ${ }^{13}$

Hasil utama dari penelitian ini adala untuk menilai perbedaan dalam ejaculatory function (EF), yang dapat Baik TURP dan ThuFLEP telah terbukti diukur dengan menggunakan five-item efektif dalam mengatasi obstruksi version of the International Index of infravesika akibat BPH. Pada enam Erectile Function (IIEF-5) sebelum bulan tindak lanjut setelah operasi, operasi dan enam bulan setelahnya. kedua teknik menghasilkan skor IIEF-5 Hasil sekunder dari penelitian ini yang sebanding. Namun apabila dilihat adalah penurunan keparahan obstruksi lebih lanjut, ThuFLEP lebih cenderung infravesika yang dapat dinilai dengan mempertahankan fungsi ereksi yang menggunakan International Prostate menyebabkan peningkatan pada skor Symptom Score (IPSS) dan maximum IIEF-5 dalam enam bulan, dibandingkan urinary flow rate (Qmax). ${ }^{14}$ dengan TURP yang menyebabkan
sedikit penurunan pada skor IIEF- $5 .{ }^{14}$ 
Sønksen $\mathrm{dkk}^{15} \quad$ Prospective, randomized, nonblinded study ${ }^{15}$

\begin{abstract}
Menggunakan 6 elemen BPH6, Penilaian elemen BPH6 individu yaitu LUTS relief yang dilihat dari mengungkapkan bahwa PUL lebih International Prostate Symptom unggul dari TURP dalam hal kualitas Score (IPSS), recovery experience pemulihan dan pengembalian fungsi yang dilihat dari quality of recovery ejakulasi. Dimana pasien yang menjalani visual analog scale (QoR VAS), erectile PUL secara signifikan merespons lebih function yang dilihat dari sexual baik daripada mereka yang menjalani health inventory for men (SHIM), TURP sebagai terapi untuk BPH dengan ejaculatory function yang dilihat dari memperhatikan aspek-aspek penting male sexual health questionnaire for dari kualitas hidup..$^{15}$ ejaculatory dysfunction (MSHQ-EjD), continence preservation yang dilihat dari incontinence severity index (ISI) Safety yang dilihat dari klasifikasi clavien-dindo. ${ }^{15}$
\end{abstract}

\section{Pembahasan}

Penelitian mengenai pengaruh terapi TURP terhadap BPH pada lansia sesuai dengan 10 artikel yang telah di-review berdasarkan kriteria kelayakan (eligible). Desain penelitian yang terdapat pada penelitian ini yaitu single-blinded RCT, prospective randomised controlled study, cohort study, single-center prospective randomized trial, retrospective study, randomized controlled trial, dan (prospective, randomized, nonblinded study). Pada penelitian ini banyak melibatkan terapi lain sebagai komparasi terapi TURP untuk melihat perbandingan outcome/ hasilnya, yaitu $1470 \mathrm{~nm}$ diode laser enucleation (DiLEP), bipolar transurethral vaporization (B-TUVP), aquablation, high-power $120 \mathrm{~W}$ greenlight HPS laser (HPS), photoselective vaporisation of the prostate (PVP), prostatic artery embolization (PAE), thulium-fiber laser enucleation (ThuFLEP), prostatic urethral lift (PUL).

Adapun terdapat satu artikel yang membandingkan hasil diantara dua jenis metode TURP yang berbeda, yaitu seperti PK-TURP dengan M-TURP dan B-TURP. Metode pengukuran pada penelitian ini sangatlah bervariasi, diantaranya dapat dievaluasi melalui risiko perdarahan, waktu operasi, waktu irigasi kandung kemih, durasi kateterisasi, durasi rawat inap, International Prostate Symptom Score (IPSS), quality of life (QoL), maximum urinary flow rate (Qmax), postvoid residual urine (PVR), serum $\mathrm{Na}+$, serum $\mathrm{K}+$, kadar hematokrit, volume cairan irigasi, kadar hemoglobin, serum kreatinin, BMI, volume prostat dasar, five-item International Index of Erectile Function scores (IIEF-5), urethral stricture rates, visual analog scale (VAS), quality of recovery visual analog scale (QoR VAS), Common Terminology Criteria for Adverse Events (CTCAE), sexual health inventory for men (SHIM), male sexual health questionnaire for ejaculatory dysfunction (MSHQEjD), incontinence severity index (ISI), dan klasifikasi clavien-dindo.

Hasil penelitian dari artikel-artikel yang telah di-review menunjukan bahwa: 1. Responden TURP adalah pria dengan $\mathrm{BPH}$ yang memiliki usia ratarata $>50$ tahun, dan ukuran prostatnya $30-80 \mathrm{~mL}$, 2. TURP memiliki tingkat kepuasan pasien tinggi dan hasil pengobatan yang cukup baik, terutama dapat meningkatkan kualitas hidup pasien BPH yang dapat dinilai dari skor IPSS, QoL, Qmax, PVR, IIEF,
CTCAE, SHIM, dan ISI, 3. TURP memiliki komplikasi yang berbeda-beda, dimana dapat dikelompokkan berdasarkan komplikasi intraoperatif dan pasca operatif. Komplikasi intraoperatif meliputi perforasi kapsul, sindrom TUR, transfusi darah, dan sklerosis leher kandung kemih. Komplikasi pasca operasi meliputi perdarahan sekunder, rekateterisasi, inkontinensia stres sementara, striktur uretra, gejala iritasi, retensi bekuan darah, infeksi saluran kemih, perdarahan yang memerlukan transfusi, disfungsi ejakulasi, disfungsi ereksi, perawatan ulang bedah, clavien-dindo o-5, demam, dan hematuria pasca operatif. Walaupun memiliki banyak risiko komplikasi, TURP masih menjadi gold standard dan memiliki banyak fungsi serta manfaat untuk perbaikan kondisi pasien BPH. Jadi kesimpulannya terapi TURP merupakan terapi dengan pengaruh yang cukup baik, efisien dan efektif.

\section{Keterbatasan Penelitian}

Analisis penelitian ini dilakukan secara kualitatif, tidak dengan kuantitatif (meta-analysis), pemilihan sampel dan metodologi dari setiap penelitian tidak sama dan kondisi komorbid lansia dengan BPH tidak sama.

\section{Simpulan}

Berdasarkan hasil dari 10 artikel penelitian mengenai pengaruh terapi TURP terhadap BPH pada lansia, maka dapat disimpulkan bahwa terapi TURP memiliki banyak fungsi serta manfaat untuk perbaikan kondisi pasien. Indikator tersebut dapat dinilai dari menurunnya risiko perdarahan, waktu operasi, waktu irigasi kandung kemih, durasi kateterisasi, durasi rawat inap, perbaikan pada IPSS, QoL, Qmax, PVR, serum $\mathrm{Na}+$, serum $\mathrm{K}+$, kadar hematokrit, volume cairan irigasi, kadar hemoglobin, serum kreatinin, volume prostat dasar, IIEF-5, CTCAE, SHIM, MSHQ$\mathrm{EjD}$, dan ISI. Pasien $\mathrm{BPH}$ dapat mengalami risiko komplikasi intraoperatif ataupun pasca operatif. Komplikasi intraoperatif meliputi perforasi kapsul, sindrom TUR, transfusi darah, dan sklerosis leher kandung kemih. Komplikasi pasca operasi meliputi perdarahan sekunder, rekateterisasi, inkontinensia stres sementara, striktur uretra, gejala iritasi, retensi 
bekuan darah, infeksi saluran kemih, perdarahan yang memerlukan transfusi, disfungsi ejakulasi, disfungsi ereksi, perawatan ulang bedah, clavien-dindo o-5, demam, dan hematuria pasca operatif. Kesimpulan penelitian ini menunjukkan bahwa pengaruh terapi TURP terhadap BPH pada lansia mempunyai hasil yang cukup baik, efisien dan efektif.

\section{Konflik Kepentingan}

Tidak ada konflik yang terjadi karena penulis sudah membaca naskah artikel dan setuju untuk dipublikasikan.

\section{Ucapan Terima Kasih}

Kami ucapkan terima kasih kepada Fakultas Kedokteran Universitas Islam Bandung yang telah memberikan penulis kesempatan untuk ikut serta dalam kegiatan penelitian ini.

\section{Daftar Pustaka}

1. Parsons JK. Benign prostatic hyperplasia and male lower urinary tract symptoms: epidemiology and risk factors. Curr Bladder Dysfunct Rep. 2010;5:212-18.

2. Chan SW. Pathology and medical therapy of benign prostatic hyperplasia. Medical Bulletin. 2011:16(6).4-8.

3. Mochtar CA, Umbas R, Soebadi DM, Rasyid N, Noegroho BS, Poernomo BB, et al. Panduan Penatalaksanaan Klinis Pembesaran Prostat Jinak (Benign Prostatic Hyperplasia/BPH). Ikatan Ahli Urologi Indonesia. 2015.

4. Gravas S, Bachmann A, Descazeaud A, Drake M, Gratzke C, Madersbacher S, Mamoulakis C, et al. Guidelines on the management of non-neurogenic male lower urinary tract symptoms (LUTS), incl. benign prostatic obstruction (BPO). European Association of Urology. 2014.

5. Otto B, Barbieri C, Lee R, Te AE, Kaplan SA, Robinson $\mathrm{B}$, et al. Incidental prostate cancer in transurethral resection of the prostate specimens in the modern era. Adv Urol. 2014;(2014):627290.

6. Zhang J, Wang X, Zhang Y, Shi C, Tu M, Shi G. $1470 \mathrm{~nm}$ Diode Laser Enucleation vs Plasmakinetic Resection of the Prostate for Benign Prostatic Hyperplasia: A Randomized Study. J Endourol.
2019 Mar;33(3):211-217.

7. Elsakka AM, Eltatawy HH, Almekaty KH, Ramadan AR, Gameel TA, Farahat Y. A prospective randomised controlled study comparing bipolar plasma vaporisation of the prostate to monopolar transurethral resection of the prostate. Arab J Urol. 2016 Nov;14(4):280-286.

8. Kasivisvanathan V, Hussain M. Aquablation versus transurethral resection of the prostate: 1 year United States - cohort outcomes. Can J Urol. 2018 Jun;25(3):9317-9322.

9. Falahatkar S, Mokhtari G, Moghaddam KG, Asadollahzade A, Farzan A, Shahab E, et al. Bipolar transurethral vaporization: a superior procedure in benign prostatic hyperplasia: a prospective randomized comparison with bipolar TURP. Int Braz J Urol. 2014 May-Jun;40(3):346-55.

10. Yang TK, Hsiao PJ, Yang HJ, Liao CH, Chiang HS, Chien KL. Body mass index and age are predictors for symptom improvement after high-power laser vaporization for benign prostatic hyperplasia. J Formos Med Assoc. 2015 Mar;114(3):268-73.

11. Sinanoglu O, Ekici S, Balci MC, Hazar AI, Nuhoglu B. Comparison of plasmakinetic transurethral resection of the prostate with monopolar transurethral resection of the prostate in terms of urethral stricture rates in patients with comorbidities. Prostate Int. 2014 Sep;2(3):121-6.

12. Sood R, Manasa T, Goel H, Singh RK, Singh R, Khattar N, Pandey P. Day care bipolar transurethral resection vs photoselective vaporisation under sedoanalgesia: A prospective, randomised study of the management of benign prostatic hyperplasia. Arab J Urol. 2017 Oct 12;15(4):331-338.

13. Müllhaupt G, Hechelhammer L, Diener PA, Engeler DS, Güsewell S, Schmid HP, Mordasini L, Abt D. Ejaculatory disorders after prostatic artery embolization: a reassessment of two prospective clinical trials. World J Urol. 2020 Oct;38(10):2595-2599.

14. Enikeev D, Glybochko P, Rapoport L, Potoldykova $\mathrm{N}$, Sukhanov R, Enikeev M, et al. Impact of endoscopic enucleation of the prostate with thulium fiber laser on the erectile function. BMC Urol. 2018 Oct;18(1).

15. Sønksen J, Barber NJ, Speakman MJ, Berges $\mathrm{R}$, Wetterauer U, Greene D, Sievert KD, et al. Prospective, randomized, multinational study of prostatic urethral lift versus transurethral resection of the prostate: 12-month results from the BPH6 study. Eur Urol. 2015 Oct;68(4):643-52. 